\title{
Penggunaan Sistem $E$-filing sebagai Tindak Kepatuhan Pelaporan SPT Tahunan Wajib Pajak Orang Pribadi pada KPP Pratama Surabaya Karangpilang
}

\author{
* Eka Nur Cahya
}

Fakultas Ekonomi dan Bisnis Universitas Bhayangkara Surabaya, Indonesia

DOI: $10.46821 /$ equity.v1i2.173

\begin{abstract}
ABSTRAK
Pembayaran pajak merupakan kontribusi terbesar bagi suatu negara dan sumber utama pendapatan suatu negara dalam pembiayaan pemerintah dan pembangunan.Salah satu upaya untuk meningkatkan kepatuhan tersebut adalah dengan membuat pembaruan sistem atau metode yang sederhana, mudah, dan cepat. Pembaruan dalam sistem perpajakan dengan penerapan teknologi informasi dalam pelayanan perpajakan yaitu dengan dilaksanakannya jenis pelayanan kepada wajib pajak dalam rangka penyampaian SPT tahunanya menggunakan elektronik atau melalui internet yang dinamakan e-Filing. Penelitian ini menggunakan metode deskriptif kualitatif dengan melakukan analisis diawali dengan pengumpulan data-data yang dibutuhkan kemudian setiap data di proses sedemikian rupa, selanjutnya data di analisis kembali untuk memperoleh gambaran mengenai permasalahan yang diteliti. Hasil penelitian ini menunjukkan Penggunaan sistem e-Filing pada KPP Pratama Surabaya Karangpilang ini belum meningkatkan kepatuhan pelaporan SPT Tahunan.Hal ini terlihat dari olahan data jumlah wajib pajak orang pribadi yang tidak melaporkan SPT Tahunannya semakin meningkat mulai tahun 2011-2017. Keterbatasan pada penelitian ini peneliti tidak memasukkan data wawancara wajib pajak orang pribadi pensiunan, jadi hanya wajib pajak orang pribadi yang produktif.
\end{abstract}

Kata Kunci: Pajak, Kepatuhan, Wajib Pajak Orang Pribadi, e-Filing, SPT Tahunan, KPP Pratama Surabaya Karangpilang

\begin{abstract}
Tax payments are the largest contribution to a country and a major source of revenue for a country in government financing and development. Tax payments aim to improve people's welfare through improved facilities and public improvement. One attempt to improve that compliance is to make system updates or methods simple, easy, and fast. The renewal in the taxation system started in 2014 is by the application of information technology in the tax service that is by the implementation of the type of service to the taxpayer in order to provide SPT year using electronic or via internet called e-Filing. This research uses descriptive qualitative method by doing the analysis begins with the collection of data required then each data in the process in such a way, then the data in the analysis back to get a picture of the problems studied. The results of this study indicate that the use of e-Filing system at KPP Pratama Surabaya Karangpilang hasn't improved the compliance of annual SPT reporting. This can be seen from the processed data of the number of individual taxpayers who do not report the Annual Tax Return is increasing from 2011-2017. Limitations in this study researchers did not include data of personal taxpayer interviews of retired private individuals, so only taxpayers are productive.
\end{abstract}

Keywords: Tax, The Compliance, Personal Taxpayer, e-Filing, SPT Tahunan, KPP Pratama Surabaya Karangpilang

*Corresponding Author:

Email: ekanurcahy@gmail.com 


\section{PENDAHULUAN}

Vol. 1 No. 22021

Pembayaran pajak merupakan kontribusi terbesar bagi suatu negara dan sumber utama pendapatan suatu negara dalam pembiayaan pemerintah dan pembangunan. Pembayaran pajak bertujuan meningkatkan kesejahteraan rakyat melalui peningkatan perbaikan dan sarana publik. Menurut UU No. 28 Tahun 2007 tentang ketentuan umum dan tata cara perpajakan yang dimaksud pajak adalah kontribusi wajib kepada negara yang terutang oleh orang pribadi atau badan yang bersifat memaksa berdasarkan undang-undang dengan tidak mendapatkan imbalan secara langsung dan digunakan untuk keperluan negara bagi sebesarbesarnya kemakmuran rakyat (Resmi, 2016:2).

Setiap wajib pajak yang terdaftar tentu memiliki Nomor Pokok Wajib Pajak (NPWP) dianggap sudah mengerti peraturan perpajakan yang berlaku. Namun kenyataannya masih banyak wajib pajak yang kurang paham tentang peraturan perpajakan bahkan masih ada wajib pajak yang sama sekali tidak mengerti mengenai peraturan perpajakan yang berlaku. Masih ada beberapa wajib pajak yang tidak sepenuhnya memahami tentang peraturan perpajakan akan berdampak pada penerimaan pajak di Indonesia. Seorang wajib pajak dapat dikatakan patuh dalam kegiatan perpajakan apabila memahami secara penuh tentang peraturan perpajakan antara lain mengetahui dan berusaha memahami Undang-Undang Perpajakan, cara pengisian formulir perpajakan, cara menghitung pajak, cara melaporkan SPT dan selalu membayar pajak tepat waktu.

Kondisi tingkat kepatuhan wajib pajak di Indonesia relatif rendah yang diakibatkan wajib pajak orang pribadi yang sudah mendaftarkan dirinya namun kemudian tidak melaporkan Surat Pemberitahuan Tahunannya (SPT), maka DJP terus berupaya menciptakan sitem perpajakan baru dalam rangka untuk meningkatkan pelayanan dan kemudahan bagi wajib pajak dalam melaporkan SPT tahunannya sehingga tingkat kepatuhan wajib pajak dapat meningkat. Salah satu upaya untuk meningkatkan kepatuhan tersebut adalah dengan membuat pembaruan sistem atau metode yang sederhana, mudah, dan cepat. Pembaruan dalam sistem perpajakan yang dimulai pada tahun 2014 ini adalah dengan penerapan teknologi informasi dalam pelayanan perpajakan yaitu dengan dilaksanakannya jenis pelayanan kepada wajib pajak dalam rangka penyampaian SPT tahunanya menggunakan elektronik atau melalui internet yang dinamakan $e$ Filing. Dengan sistem e-Filing yang dibuat oleh Direktorat Jendral Pajak tujuannya dapat meningkatkan pelayanan kepada wajib pajak dan diharapkan dapat meningkatnya kepatuhan wajib pajak dalam pelaporan Surat Pemberitahuan Tahunan wajib pajak orang pribadi.Dengan adanya sistem ini penulis ingin mengetahui apakah wajib pajak orang pribadi menjadi lebih patuh atau tidak.

Adanya sistem pelaporan pajak dengan menggunakan e-filling dapat memudahkan wajib pajak. Wajib pajak dapat melaporkan SPTnya 24 jam dan wajib pajak juga dapat melaporkan SPTnya pada saat hari libur. Sistem ini sangat bermanfaat untuk wajib pajak yang tidak dapat melaporkan SPTnya dengan alasan kesibukannya.

Menurut penelitian Risal C. Y. Laihad (2103) tentang pengaruh perilaku wajib pajak terhadap penggunaan e-Filing wajib pajak di kota Manado memaparkan bahwa presepsi kegunaan dan kemudahan berpengaruh positif dan signifikan terhadap penggunaan e-Filing. Penelitian Ivana Lie dan Arja Sadjiarto (2013) tentang faktor-faktor yang mempengaruhi minat perilaku wajib pajak 
untuk menggunakan e-Filing memaparkan bahwa faktor presepsi terhadap kegunaan, faktor presepsi kemudahan, faktor social, dan faktor kesukarelaan berpengaruh terhadap minat wajib pajak dalam menggunakan $e$-Filing. Pendapat Wulandari Agustiningsih (2016) dari hasil penelitian tentang pengaruh penerapan e-Filing, tingkat pemahaman perpajakan dan kesadaran wajib pajak terhadap kepatuhan wajib pajak di KPP Pratama Yogyakarta memaparkan bahwa penerapan $e$-Filing berpengaruh positif dan signifikan terhadap kepatuhan wajib pajak di KPP Pratama Yogyakarta. Menurut penelitian Abdurrohman, dkk (2015) tentang Implementasi program e-Filing dalam upaya peningkatan kepatuhan Wajib Pajak Orang Pribadi (Studi pada Kantor Pelayanan Pajak Pratama Bojonegoro) mamaparkan bahwa implementasi e-Filing belum berperan secara optimal dalam peningkatan kepatuhan pajak, hal ini terjadi karena $e$-Filing belum mampu menhilangkan factor perbedaan individu yang berpengaruh pada tingkat kepatuhan wajib pajak.

Uraian beberapa penelitian yang dilakukan sebelumnya yang memiliki hasil berbeda dengan penulis yang mengkaji pada penggunaan sistem $e$-Filing sebagai tindak kepatuhan pelaporan SPT Tahunan wajib pajak berdasarkan kenyataan bahwa kepatuhan wajib pajak masyarakat Indonesia masih rendah. Sebagi rujukan peneliti di KPP Surabaya Karang Pilang yang menjadi obyek untuk penelitian karena KPP Tersebut pada tahun 2017 telah menjadi Kantor Pelayanan Percontohan (KPPc) terbaik tingkat Kementrian Keuangan, dengan memiliki predikat "Zona Anti Korupsi".

Berdasarkan uraian tersebut, maka penulis tertarik untuk meneliti dengan judul penggunaan sistem E-Filing sebagai tindak kepatuhan pelaporan SPT Tahunan Wajib Pajak Orang Pribadi pada KPP Pratama Surabaya Karang Pilang.

\section{METODE PENELITIAN}

Penelitian ini menggunakan metode deskriptif kualitatif dengan melakukan analisis diawali dengan pengumpulan data-data yang dibutuhkan kemudian setiap data yang ada kemudian di proses sedemikian rupa sehingga data yang diperoleh menjadi lebih sederhana, selanjutnya data di analisis kembali untuk memperoleh gambaran yang lebih jelas mengenai permasalahan yang diteliti. Setelah memperoleh gambaran yang lebih jelas maka setiap data disajikan secara lengkap sehingga diharapkan dapat menjawab setiap permasalahan yang dialami tentang penerapan e-Filing dalam upaya peningkatan kepatuhan Wajib Pajak Orang Pribadi pada KPP Pratama Karang Pilang, kemudian ditarik kesimpulan dengan hasil penelitian yang dilakukan.

Data adalah sekumpulan informasi yang diperlukan untuk pengambilan keputusan. Jenis data dapat dibagi menjadi dua, yaitu:

1. Data kualitatif, yang berupa :

a. Pengenalan dan gambaran umum mengenai objek penelitian yaitu KPP Pratama Karang Pilang.

2. Data kuantitatif, yang berupa :

a. Data Jumlah Wajib Pajak Terdaftar di KPP Pratama Karang Pilang, tahun 2011-2017.

b. Data Jumlaah Wajib Pajak yang telah meminta e-FIN di KPP, tahun 20112017. 
c. Data Jumlah Wajib Pajak yang melapor pajak menggunakan e-Filing, dan SPT Manual dengan tepat waktu, tahun 2011-2017.

d. Data Jumlah Wajib Pajak yang melapor pajak menggunakan e-Filing, dan SPT Manual dengan tidak tepat waktu, tahun 2011-2017.

Data Jumlah Wajib Pajak yang melapor SPT Tahunan sebelum penerapan $e$ Filing, tahun 2011-2017.

\section{HASIL DAN PEMBAHASAN}

Kepatuhan wajib pajak dalam kewajiban perpajakannya dapat dilihat dari beberapa faktor, misalnya berdasarkan pertumbuhan jumlah orang pribadi terdaftar, pertumbuhan orang pribadi efektif, peningkatan atau penurunan kepatuhan dalam pelaporan SPT Pajak (Tabel 1).

Dari informasi tersebut bahwa pada dasarnya Wajib Pajak Orang Pribadi di KPP Pratama Surabaya Karangpilang selalu mengalami peningkatan dari tahun ke tahun. Peningkatan jumlah Wajib Pajak Orang Pribadi disebabkan oleh adanya Wajib Pajak Orang Pribadi baru, selain itu adanya Wajib Pajak Orang Pribadi yang keluar karena pindah ke wilayah lain yang berbeda Kantor Wilayah ataupun Wajib Pajak Orang Pribadi yang masuk karena pindah dari KPP lain.

Wajib pajak terdaftar merupakan seluruh wajib pajak yang tercatatat di KPP dalam satu tahun pajak yaitu wajib pajak yang telah memiliki NPWP.Namun wajib pajak terdaftar tidak seluruhnya memenuhi kewajiban perpajakannya, sebagian dari wajib pajak terdaftar merupakan wajib pajak non efektif.Wajib pajak non efektif adalah wajib pajak yang telah melaporkan dirinya dan membuat pernyataan bahwa wajib pajak tersebut sudah tidak berpenghasilan lagi.Dalam penelitian ini yang dimakasudkan wajib pajak efektif adalah wajib pajak yang masih berpenghasilan.

Wajib Pajak Orang Pribadi yang efektif merupakan seluruh Wajib Pajak Orang Pribadi yang telah memiliki kewajiban perpajakan.Namun Wajib Pajak Orang Pribadi yang efektif tidak sepenuhnya memenuhi kewajiban perpajakannya.Sebagian dari wajib pajak efektif merupakan wajib pajak yang memiliki NPWP Pusat dan wajib pajak yang memiliki NPWP dengan status NPWP cabang.Wajib pajak cabang tidak memiliki kewajiban untuk melaporkan SPT. Dalam penelitian ini yang dimaksudkan wajib pajak pusat adalah wajib pajak yang tiap tahunnya wajib melaporkan SPT Tahunannya.

Tabel 1

Data WPOP Tahun 2011-2017

\begin{tabular}{ccccc}
\hline $\begin{array}{l}\text { Tahun } \\
\text { Pajak }\end{array}$ & $\begin{array}{l}\text { WPOP } \\
\text { Efektif }\end{array}$ & WPOP Non Efektif & WPOP Terdaftar & Presentase \\
\hline 2011 & 21.824 & 11.239 & 33.063 & $66,01 \%$ \\
2012 & 23.689 & 12.331 & 36.020 & $65,77 \%$ \\
2013 & 25.815 & 13.269 & 39.084 & $66,05 \%$ \\
2014 & 28.066 & 14.118 & 42.184 & $66,53 \%$ \\
2015 & 30.713 & 14.504 & 45.217 & $67,92 \%$ \\
2016 & 33.934 & 14.571 & 48.505 & $69,96 \%$ \\
2017 & 36.789 & 14.594 & 51.383 & $71,60 \%$ \\
\hline
\end{tabular}

Sumber: Seksi Pengolahan Data dan Informasi (PDI) 
Tabel 2

Data WPOP Wajib SPT dan WPOP Tidak Wajib SPT Tahun 2011-2017

\begin{tabular}{ccccc}
\hline $\begin{array}{l}\text { Tahun } \\
\text { Pajak }\end{array}$ & WPOP & $\begin{array}{c}\text { WPOP Wajib } \\
\text { Efektif }\end{array}$ & $\begin{array}{c}\text { WPOP Tidak Wajib } \\
\text { SPT Tahunan }\end{array}$ & Presentase \\
\hline 2011 & 21.824 & 21.688 & 136 & $99,38 \%$ \\
2012 & 23.689 & 23.527 & 162 & $99,32 \%$ \\
2013 & 25.815 & 25.632 & 183 & $99,29 \%$ \\
2014 & 28.066 & 27.861 & 205 & $99,27 \%$ \\
2015 & 30.713 & 30.485 & 228 & $99,26 \%$ \\
2016 & 33.934 & 33.695 & 239 & $99,30 \%$ \\
2017 & 36.789 & 36.544 & 245 & $99,33 \%$ \\
\hline
\end{tabular}

Sumber: Seksi Pengolahan Data dan Informasi (PDI)

Tabel 3

Data Pelaporan SPT Tahunan WPOP melalui e-Filing dan Manual Tahun 2011-2017

\begin{tabular}{ccccc}
\hline $\begin{array}{l}\text { Tahun } \\
\text { Pajak }\end{array}$ & $\begin{array}{c}\text { Tahun } \\
\text { Penerimaan }\end{array}$ & e-Filing & Manual & Total \\
\hline 2011 & 2012 & 10 & 18.351 & 18.361 \\
2012 & 2013 & 55 & 19.533 & 19.588 \\
2013 & 2014 & 2.064 & 18.975 & 21.039 \\
2014 & 2015 & 4.822 & 17.044 & 21.866 \\
2015 & 2016 & 9.666 & 14.044 & 23.710 \\
2016 & 2017 & 12.225 & 11.425 & 23.650 \\
2017 & 2018 & 18.648 & 3.341 & 21.989 \\
\hline
\end{tabular}

Sumber: Seksi Pengolahan Data dan Informasi (PDI)

Tabel 4

Data WPOP yang Tidak Menyampaikan SPT Tahunan pada Tahun 2011-2017

\begin{tabular}{lcrrrr}
\hline $\begin{array}{c}\text { Tahun } \\
\text { Pajak }\end{array}$ & $\begin{array}{c}\text { Tahun } \\
\text { Penerimaan }\end{array}$ & $\begin{array}{c}\text { WPOP } \\
\text { Wajib SPT } \\
\text { Tahunan }\end{array}$ & $\begin{array}{c}\text { SPT } \\
\text { Tahunan } \\
\text { WPOP }\end{array}$ & $\begin{array}{c}\text { Menyampaikan } \\
\text { SPT Tahunan }\end{array}$ & Presentase \\
\hline 2011 & 2012 & 21.688 & 18.361 & 3.327 & $15,34 \%$ \\
2012 & 2013 & 23.527 & 19.588 & 3.939 & $16,74 \%$ \\
2013 & 2014 & 25.632 & 21.039 & 4.593 & $17,92 \%$ \\
2014 & 2015 & 27.861 & 21.866 & 5.995 & $21,52 \%$ \\
2015 & 2016 & 30.485 & 23.710 & 6.775 & $22,22 \%$ \\
2016 & 2017 & 33.695 & 23.650 & 10.045 & $29,81 \%$ \\
2017 & 2018 & 36.544 & 21.989 & 14.555 & $39,83 \%$
\end{tabular}

Sumber: Seksi Pengolahan Data dan Informasi (PDI)

Berdasarkan data diatas terlihat bahwa pelaporan SPT Tahunan dengan menggunakan e-Filing dari tahun ke tahun semakin meningkat. 
Tabel 5

Presentase WPOP yang Melaporkan SPT Tahunan pada Tahun 2011-2017

\begin{tabular}{ccrrr}
\hline Tahun Pajak & $\begin{array}{c}\text { Tahun } \\
\text { Penerimaan }\end{array}$ & $\begin{array}{c}\text { WPOP Wajib SPT } \\
\text { Tahunan }\end{array}$ & $\begin{array}{c}\text { SPT Tahunan } \\
\text { WPOP }\end{array}$ & Presentase \\
\hline 2011 & 2012 & 21.688 & 18.361 & $84,66 \%$ \\
2012 & 2013 & 23.527 & 19.588 & $83,26 \%$ \\
2013 & 2014 & 25.632 & 21.039 & $82,08 \%$ \\
2014 & 2015 & 27.861 & 21.866 & $78,48 \%$ \\
2015 & 2016 & 30.485 & 23.710 & $77,77 \%$ \\
2016 & 2017 & 33.695 & 23.650 & $70,19 \%$ \\
2017 & 2018 & 36.544 & 21.989 & $60,15 \%$ \\
\hline
\end{tabular}

Sumber: Seksi Pengolahan Data dan Informasi (PDI)

Berdasarkan hasil wawancara oleh Berdasarkan hasil wawancara dengan Bapak Barkat selaku seksi Pengolahan Data dan Informasi di KPP Pratama Surabaya Karangpilang, pada tanggal 28 Mei 2018 mengatakan bahwa :

"Data jumlah berapa WPOP yang meminta e-FIN tersebut tidak dapat dilihat oleh internal, karena tidak ada aksesnya.Database tersebut tidak ada di sistem, database tersebut tidak dibuka oleh DJP.Pada KPP Pratama Surabaya Karangpilang tidak mempunyai data berapa WPOP yang sudah meminta eFIN.Hal tersebut dapat dilihat dari satu orang satu untuk login tertentu, namun tidak semua dapat login, karena tergantung jabatannya.Jadi kita dapat melihat siapa yang sudah mempunyai e-FIN atau belum tapi untuk jumlahnya tidak ada dan hal tersebut merupakan privasi WPOP. Saya sudah mencoba bertanya kepada orang kantor pusat bagian data tapi dia juga tidak punya karena tidak ada dan tidak diberi aksesnya. Namun diperkirakan hingga saat ini ada 40\% WPOP yang telah meminta e-FIN."

Berdasarkan hasil pengolahan data diatas menujukkan bahwa penyampaian SPT Tahunan dengan sistem e-Filing ini tidak mengalami peningkatan melainkan mengalami penurunan.Hal ini dapat terlihat dari data WPOP yang tidak menyampaikan SPT Tahunan yang terus mengalami peningkatan disetiap tahunnya.Jumlah penyampaian SPT Tahunan dengan adanya sistem e-Filing memang meningkat dibandingkan dengan tahun sebelumnya, namun peningkatan ini tidak sebanding dengan peningkatan WPOP Wajib SPT Tahunan.Hal ini membuat kepatuhan WPOP SPT Tahunan di KPP Surabaya Karangpilang dengan adanya penerapan sistem e-Filing melalui website DJP tidak mengalami peningkatan.

Intensitas yang akan dicapai dalam penelitian ini berupa adanya peningkatan kepatuhan perajakan secara sukarela dengan tujuan untuk mengetahui apakah penerapan e-Filing menyampaikan pelaopran SPT Tahunan lebih tepat waktu serta apakah sistem e-Filing dapat meningkatkan kepatuhan WPOP dibandingkan sebelum diterapkannya sistem e-Filing. Keterbatasan pada penelitian ini peneliti tidak memasukkan data wawancara wajib pajak orang pribadi pensiunan, jadi hanya wajib pajak orang pribadi yang produktif.

\section{SIMPULAN}

Berdasarkan hasil penelitian yang telah dilakukan tentang Penggunaan Sistem eFiling Sebagai Tindak Kepatuhan Pelaporan SPT Tahunan Wajib Pajak Orang Pribadi pada KPP Pratama Surabaya Karangpilang dapat disimpulkan sebagai berikut: Penggunaan sistem e-Filing pada KPP Pratama Surabaya Karangpilang 
ini belum meningkatkan kepatuhan pelaporan SPT Tahunan. Hal ini terlihat dari olahan data jumlah WPOP yang tidak melaporkan SPT Tahunannya semakin meningkat mulai tahun 2011-2017. Berdasarkan hasil pengamatan dan temuan peneliti ketika melaporkan SPT Tahunan WPOP di KPP Pratama Surabaya Karangpilang sudah cukup efektif karena sudah berusaha memaksimalkan SDM dan sarana prasarana yang ada untuk membantu WPOP yang belum bisa menggunakan aplikasi e-Filing. Hal ini dapat memberikan pemahaman mengenai e-Filing bagi WPOP tentang tata cara pelaporannya yang cukup mudah, efisien, efektif, dan hemat waktu. Hanya saja kebanyakan wajib pajak yang datang untuk menyampaikan SPT Tahunannya selalu pada akan berkahirnya masa pelaporan SPT Tahunan. Berdasarkan hasil penelitian yang dilakukan, saran yang dapat diberikan sehubungan dengan hasil penelitian dan keterbatasan penelitian adalah sebagai berikut: 1) Untuk meningkatkan kepatuhan pelaporan SPT Tahunan WPOP pada KPP Pratama Surabaya Karangpilang sebaiknya KPP dan DJP memberikan sosialisasi secara langsung kepada wajib pajak orang pribadi, terutama pada WPOP yang baru memiliki NPWP. Dengan cara seperti memberikan INTIM (Informasi Tiga Menit) tidak hanya kepada WPOP usahawan melainkan kepada WPOP pekerjaan bebas, dan WPOP karyawan. Selain itu untuk sosialisasi melalui media masa dan sosial sebaiknya tidak dilakukan pada bulan ketika waktu penyampaian SPT Tahunan saja (Januari-Maret). 2) Sebaiknya bagi wajib pajak yang hendak menyampaikan SPT Tahunannya tidak melaporkan SPT Tahunannya secara mendadak atau tidak mendekati masa berakhirnya pelaporan SPT Tahunan agar ketika mengalami kesulitan untuk mengisi SPT tersebut dapat di bimbing dengan semaksimal mungkin oleh KPP Pratama Surabaya Karangpilang.

\section{DAFTAR PUSTAKA}

Abdurrohman, Sisilia, Tjahjanulin, Domai, dan Muhammad, Shobaruddin. 2015, Implementasi Program e-Filing Dalam Upaya Peningkatan Kepatuhan Wajib Pajak Orang Pribadi (Studi pada Kantor Pelayanan Pajak Pratama Bojonegoro), Jurnal Administrasi Publik, vol. 3 no.5, Retieved 27 Desember 17, from https://media.neliti.com/media/publications/81869-ID implementasi-program-e-filing-dalam-upay.pdf

Agustian, Widi.2011,Pengantar Ilmu Hukum Pajak. PT. Gramedia, Jakarta.

Agustiningsih, Wulandari. 2016, Pengaruh Penerapan e-Filing, Tingkat Pemahaman Perpajakan dan Kesadaran Wajib Pajak Terhadap Kepatuhan Wajib Pajak di KPP Pratama Yogyakarta, Skripsi, Universitas Negeri Yogyakarta, Yogyakarta.

Dewi, Fionora, Pravita. 2017, Implementasi Sistem e-Filing Terhadap Kepatuhan Wajib Pajak Dalam Penyampaian SPT Tahunan pada KPP Pratama Surabaya Rungkut, Skripsi, Sekolah Tinggi Ilmu Ekonomi Indonesia, Surabaya. 
Direktorat Jendral Pajak. 2014,Peraturan Direktur Jendral Pajak Nomor PER1/PJ/2014 Tentang Tata Cara Penyampaian Surat Pemberitahuan Tahunan Bagi Wajib Pajak Orang Pribadi yang Menggunakan Formulir 1770S Atau 1770SS Secara E-Filing Melalui Website Direktorat Jenderal Pajak (Www.Pajak.Go.Id), Jakarta.

Direktorat Jendral Pajak. 2017, Peraturan Direktorat Jendral Pajak Nomor PER01/PJ/2017 Tentang Penyampaian Surat Pemberitahuan Elektronik, Jakarta.

Hamidi. 2005,Metode Penelitian Kualitatif : Aplikasi Praktis Pembuatan Proposal dan Laporan Penelitian,UMM PRESS, Malang.

Havid, Mohamad. 2014, Pengaruh Penerapan e-Filing Terhadap Tingkat Kepatuhan Wajib Pajak (Studi Survey Pada Kantor Pelayanana Pajak Pratama Bandung Cibeunying), Skripsi, Universitas Widyatama, Bandung.

Jogiyanto, Hartono. 2013, Metodologi Penelitian Bisnis : Salah Kaprah dan Pengalaman-Pengalaman, Edisi Keenam, BPFE Yogyakarta, Yogyakarta.

Laihad, Risal C.Y. 2013, Pengaruh Perilaku Wajib Pajak Terhadap Penguunaan eFiling Wajib Pajak di Kota Manado, Jurnal EMBA, vol. 1, no.3.Retieved 26 Desember 17, from https://media.neliti.com/media/publications/1624-IDpengaruh-perilaku wajib-pajak-terhadap-penggunaan-e-filing-wajib-pajakdi-kota-m.pdf

Lie, Ivana, dan Arja, Sadjiarto. 2013,Faktor-Faktor Yang Mempengaruhi Minat Perilaku Wajib Pajak Untuk Menggunakan e-Filing, Jurnal Tax \& Accounting Review, vol. 3, no.2. Retieved 26 Desember 17, from https://media.neliti.com/media/publications/157289-ID-none.pdf

Mardiasmo. 2011,Perpajakan, Edisi Revisi,Ansi, Yogyakarta.

Natali S, Nie, Debby. 2016, Penerapan Sistem Pelaporan Pajak dengan e-Filing dan Pengaruhnya Terhadap Kepatuhan Wajib Pajak Orang Pribadi pada Badan Pusat Statistik (BPS) Provinsi Jawa Tengah, Skripsi, Universitas Dian Suswantoro, Semarang.

Nazir, Mohammad.2011,Metode Penelitian, Ghalia Indonesia, Jakarta.

Nurhidayah, Sari. 2015, Pengaruh Penerapan Sistem e-Filing Terhadap Kepatuhan Wajib Pajak Dengan Pemahaman Internet Sebagai Variabel Pemoderasi Pada KPP Pratama Klaten, Skripsi, Universitas Negeri Yogyakarta, Yogyakarta. 
Pudyatmoko, Y. Sri.2009,Pengantar Hukum Pajak, Edisi Revisi, Andi, Yogyakarta.

Resmi, Siti. 2016, Perpajakan: Teori dan Kasus, Edisi 9, Jakarta, Salemba Empat.

Sugiyono.2014, Metode Penelitian Pendidikan Pendekatan Kuantitatif, Kualitatif, dan R\&D, Alfabeta, Bandung.

Supramono,\& Damayanti T.W. 2010,Perpajakan indonesia : Mekanisme dan Perhitungan, Andi, Yogyakarta.

Widodo, Widi.2010,Moralitas Budaya dan Kepatuhan Pajak, Alfabeta, Bandung.

Zain, Mohammad.2008,Manajemen Perpajakan,Salemba Empat, Jakarta. 